\title{
Building resilience to climate change in vulnerable communities: A case study of uMkhanyakude district municipality
}

\section{Anele Mthembu \& Syathokoza Hlophe}

\section{DOI: $h t t p: / / d x . d o i . o r g / 10.18820 / 2415-0495 / t r p 77 i 1.4$}

Peer reviewed and revised October 2020

Published December 2020

*The authors declared no conflict of interest for this title or article

\begin{abstract}
Climate change in South Africa remains an issue of socio-economic and environmental concern. An increase in frequency and intensity of climatic events pose significant threats to biophysical and socio-economic aspects, namely food security, water resources, agriculture, biodiversity, tourism, and poverty. In order to counteract the socio-economic and environmental concerns pertaining to issues of climate change, emergent insights on climate change strategies suggest that building resilience in human and environmental systems is an ideal way of combating dynamic environmental conditions and future uncertainties. Using the qualitative secondary data approach, this article evaluates whether vulnerable communities in uMkhanyakude District Municipality can become resilient to the implications of climate change. UMkhanyakude District Municipality is predominantly rural and one of the most impoverished districts in KwaZulu-Natal, with the majority of socially and economically marginalised individuals and households experiencing more severe impacts as a result of climate change compared to those in urban areas. Data was analysed using content analysis and a concise summary of the biophysical and socio-economic aspects is presented. This research suggests that building resilience to climate change is possible when bottom-up, proactive and systematic measures are taken to manage vulnerable areas such as those in uMkhanyakude District Municipality. It recommends that social impact assessments (SIA) be conducted to assist in terms of assessing social consequences that are likely to follow from policy actions.
\end{abstract}

Keywords: Adaptation, climate change, resilience, vulnerability

\section{BOU VEERKRAGTIGHEID TEEN KLIMAATSVERANDERING IN KWESBARE GEMEENSKAPPE: 'N GEVALLESTUDIE VAN UMKHANYAKUDE-DISTRIKSMUNISIPALITEIT}

Klimaatsverandering in Suid-Afrika bly 'n kwessie van maatskaplike ekonomiese en omgewingsbelang. Terwyl daar 'n toename is in frekwensie en intensiteit van klimaatsgebeurtenisse, is daar steeds beduidende bedreigings vir biofisiese en sosio-ekonomiese aspekte, naamlik voedselsekerheid, waterbronne, landbou, biodiversiteit, toerisme en armoede. Ten einde die sosio-ekonomiese en omgewingskwessies rakende klimaatsverandering teë te werk, dui opkomende insigte oor klimaatsveranderingstrategieë daarop dat veerkragtigheid in menslike en omgewingstelsels ' $n$ ideale manier is om dinamiese omgewingstoestande en toekomstige onsekerhede te bekamp. Met behulp van die kwalitatiewe sekondêre databenadering, evalueer hierdie artikel of kwesbare gemeenskappe in uMkhanyakude-distriksmunisipaliteit veerkragtig kan raak teen die gevolge van klimaatsverandering. UMkhanyakudedistriksmunisipaliteit is oorwegend landelik en een van die armste distrikte in KwaZulu-Natal, met 'n meerderheid sosiale en ekonomies gemarginaliseerde individue en huishoudings wat baie erger gevolge ervaar as gevolg van klimaatsverandering in vergelyking met dié in stedelike gebiede. Data is met behulp van inhoudsanalise geanaliseer en ' $n$ bondige opsomming van die biofisiese en sosio-ekonomiese aspekte is aangebied. Hierdie navorsing dui daarop dat die bou van veerkragtigheid teenoor klimaatsverandering moontlik is as gevolg van onder, proaktiewe en stelselmatige maatreëls om kwesbare gebiede soos dié in uMkhanyakudedistriksmunisipaliteit te bestuur. Die artikel beveel aan dat maatskaplike impakstudies (SIA) gedoen word om te help met die beoordeling van maatskaplike gevolge wat waarskynlik uit beleidsaksies kan volg.

Sleutelwoorde: Aanpassing, klimaatsverandering, kwesbaarheid, veerkragtigheid

\section{HO AHA MAMELLO EA PHETOHO EA MAEMO A LEHOLIMO METSENG E TLOKOTSING: PHUPUTSO EA MASEPALA OA SETEREKE SA UMKHANYAKUDE}

Phetoho ea maemo a leholimo Afrika Boroa e ntse e le taba ea ngongoreho ea sechaba, moruo le tikoloho. Ho nyoloha hoa maqhubu le matla a liketsahalo tsa maemo a leholimo li tlisa tlokotsi likarolong tsa tikoloho, sechaba le moruo, e leng ts'ireletso ea lijo, lisebelisoa tsa metsi, temo, mefuta-futa ea bochaba, bohahlauli le bofuma. Bakeng sa ho loants'a mathata a sechaba, moruo le tikoloho mabapi le litaba tsa phetoho ea maemo a leholimo, leseli le hlahang mabapi le maano a phetoho ea maemo a leholimo le fana ka maikutlo a hore, ho aha botsitso litsing tsa batho le tsa tikoloho ke tsela e nepahetseng ea ho loants'a maemo a tikoloho le phapang e ka tlisoang ke bokamoso. Ka ts'ebeliso ea mokhoa oa boleng bo holimo oa lipatlisiso, sengoloa sena se lekola hore na sechaba se tlokotsing seterekeng sa Mmasepala sa uMkhanyakude se ka khona ho mamella

Miss Anele Mthembu, eThekwini Municipality, Candidate Planner, P.O. Box 680, Durban, 4001. Phone: 0837756749, email: <anelemthembu@gmail. com>, ORCID: https://orcid.org/0000-0003-0622-1907.

Miss Syathokoza Portia Hlophe, KZN EDTEA, Environmental Officer, Private Bag X2055, Dundee, 3000. Phone: 0730831599, email: <syathokozahlophe@gmail.com>, ORCID: https://orcid.org/0000-0003-3182-833X. 
litlamorao tsa phetoho ea maemo a leholimo. Masepala oa Setereke oa UMkhanyakude o mahaeng haholo 'me setereke sena ke seseng sa litereke tse futsanehileng ka ho fetisisa KwaZuluNatal, ka bongata ba batho le malapa a sotlehileng sechabeng le moruong, moo ho bileng ho nang le litlamorao tse mpe ka lebaka la phetoho ea maemo a leholimo ha a bapisoa le a libakeng tsa litoropo. Linthla li ile tsa hlahlojoa ho sebelisoa thaiso-leseling le kakaretso ea likarolo tsa thaho ea bophelo le moruo. Phuputso ena e fana ka maikutlo a hore ho aha boits'oaro ba phetoho ea maemo a leholimo ho a khonahala ha mehato e nkuoang ho laola libaka tse tlokotsing joalo ka tse Masepaleng oa Setereke sa uMkhanyakude, ele e hlophisehileng e bile e kenyeletsa maikutlo a sechaba. E khothaletsa hore litekolo tsa sekhahla sa kahisano (SIA) di etsoe ho thusa mabapi le ho lekola litlamorao tsa kahisano tse ka bang teng ho latela liketso tsa maano.

\section{INTRODUCTION}

Climate change is defined as any changes in climate over time, due to natural variability or human activities (IPCC, 2007: 6). Although climate naturally changes, there is a growing concern about the changes in climate due to anthropogenic activities (Henderson, Storeygard \& Deichmann, 2017: 60). Climate change is now a scientifically proven issue and poses life-threatening impacts on human beings and ecosystems. While the impacts of climate change in Africa are more severe, the continent continues to be more vulnerable to climate change as a result of high exposure and low adaptive capacity (Conway, 2009: 11; Gbetibouo, Ringler \& Hassan, 2010: 177). According to Schilling, Hertig, Tramblay \& Scheffran (2020: $3)$, South Africa is more implicated with climate change, due to the high dependence on rain-fed agriculture, coupled with poor technical, financial and institutional capacity. Agriculture is considered one of the main economic activities in South Africa, with over $60 \%$ of the population in this field, and it contributes approximately $50 \%$ to the Gross Domestic Product (GDP). Although climate change is regarded as a global issue, its implications are not anticipated to be homogeneous, but different across generations, classes, regions, income groups, and gender (Mbow, Rosenzweig, Barioni, Benton, Herrero \& Krishnapilla et al., 2019: 464).

Climate change has been considered the most prevalent environmental concern in South Africa, as the country's mean annual temperatures have increased at least 1.5 time compared to the observed global average of $0.65^{\circ} \mathrm{C}$ over the past fifty years, with an increase in frequency and intensity, due to extreme climatic events (Ziervogel, New, Archer Van Garderen, Midgley, Taylor \& Hamann et al., 2014: 605). Catastrophic events such as droughts, floods, tropical cyclones, and urban heat islands pose a significant threat to food security, water resources, infrastructure, tourism, ecosystem services, and biodiversity (Huq, Hugè, Boon \& Gain, 2015: 8438; Ziervogel et al., 2014: 606).

The threat of climate change on food security, water resources, tourism, ecosystem services and biodiversity challenges national development, due to South Africa's high levels of poverty and inequality (Ziervogel et al., 2014: 606). Climate change projections in South Africa suggest a substantial warming of $5^{\circ} \mathrm{C}-8^{\circ} \mathrm{C}$ in the interior, wetter conditions along the eastern portion of the country, and drier conditions to the west and south of the country (DoEA, 2013). As an outcome, south-western parts of the country are projected to become drier, especially during the winter months, and a shortened winter rainfall is expected. The northern and eastern parts of the country are expected to experience an increase in rainfall during the summer months that may potentially cause flooding. Furthermore, drought incidents are also expected to proliferate throughout the country.

Studies show that South Africa is susceptible to droughts and $\mathrm{El}$ Nino Southern Oscillation (ENSO), which sometimes causes extreme droughts (Baudoin, Vogel, Nortje \& Naik, 2017: 128). In 2015 and 2016, the country experienced an El Nino-induced drought, the severity of which resulted in the implementation of water restrictions in several cities such as Johannesburg and Cape Town (Enqvist \& Ziervogel, 2019: 7).
Following these mitigation plans, South Africa experienced a massive reduction in crop production as a result of these droughts. The drought severity in the country has been increasing to a point where, on 4 March 2020, the Minister of CoOperative Governance and Traditional Affairs declared a state of drought disaster in the country (De Wet, 2020).

According to Adams, Álvarez-Romero, Capon, Crowley, Dale, Kennard, Douglas \& Pressey (2017: 57), to counteract the country's vulnerability to climate change, emergent insights on climate change strategies suggest that building resilience in human and environmental systems is an ideal way of dealing with dynamic environmental conditions and future uncertainties. Therefore, this article evaluates whether communities in uMkhanyakude District Municipality could become resilient to climate change implications, given their vulnerability. The purpose of using uMkhanyakude District Municipality as a case study is due to the geoeconomic setting of the area being predominantly rural and regarded as the poorest district municipality in KwaZulu-Natal. Studies have noted that such communities are vulnerable and lack the ability to adapt to climate change impacts, due to poor technical, financial and institutional capacity (Schilling et al., 2020: 3). As a result, this article focuses on climate change impacts, and its cascading consequences and the livelihood impacts on vulnerable communities especially in rural areas, in order to inform a bottom-up, systematic and proactive way of becoming resilient.

\section{LITERATURE REVIEW}

\subsection{Climate change policies and programmes}

South Africa is committed to addressing climate change issues, as it is a signatory to both the United Framework Convention on Climate Change (UNFCCC) and the Kyoto Protocol in terms of its efforts in reducing greenhouse gases. In addition, South Africa has also adopted the Sustainable 
Development Goals (SDGs), with Goal 1 seeking, to "end poverty in all its forms everywhere". Target 1.5 states that by 2030 , the world must "build the resilience of the poor and those in vulnerable situations and reduce their exposure and vulnerability to climate related extreme events and other economic, social, and environmental shocks and disasters". Furthermore, Goal 13 focuses purely on climate change, calling on "urgent action to combat climate change and its impacts". Target 13.1 states that we must "strengthen resilience and adaptive capacity to climate-related hazards and natural disasters in all countries" (UN, 2016).

Nationally, the overall policy framework for climate change is the National Climate Change Response Policy (NCCRP), which was set out in the National Climate Change Response White Paper (NCCRWP) enacted in 2011. The NCCRWP is informed by the South African Constitution 1996, Section $24^{1}$, the Bill of Rights, the National Environmental Management Act (No. 107 of 1998), the agreements made at the UNFCCC, and the Millennium Agreement. During June 2018, there was a public participation process on a draft Climate Change Bill that would have specific objectives and laws for climate change (Averchenkova, Gannon \& Curran, 2019: 12). The Disaster Management Amended Act (No. 16 of 2015) aims to provide measures for the disaster risk reduction through adaptation to climate change and development of early warning systems. In addition, a draft National Climate Change Adaptation (NCCA) strategy was released in 2017, but Cabinet has not adopted it. While South Africa has progressive climate change policies, implementation has been hindered by various issues such as the lack of policy alignment, coherence and coordination; policy complexity and continuity; issues with public-private engagement and consultation; gaps and constraints in information and data, and limited staff capacity at the

1 "Everyone has a right to a healthy and safe environment". municipal level (Averchenkova et al., 2019: 2). Studies suggest that, even if South Africa is committed to implementing those climate change policies, the country is still grappling with development issues such as poverty, lack of access to basic services, and the high unemployment rate (Segal \& Cloete, 2012: Greenpeace Africa, 2015).

\section{Chapter 5 of the National}

Development Plan (NDP) details the transition to a low-carbon economy as a response to climate change. The NDP acknowledges that the country is vulnerable to the impacts of climate change, with additional threats to livelihoods, health, water, and food, especially for the poor, women and children (NDP, 2012: 33). While this is the case, there is an inherent vulnerability of poor communities to environmental threats and pressures of a resourcebased economy (NDP, 2012: 198). ${ }^{2}$ Unfortunately, South Africa's capacity to effectively respond to climate change is compromised by factors such as social vulnerability, dispersed and poorly planned development, as well as lack of infrastructure, instead of systematic climate-specific interventions (NDP, 2012: 200). This has resulted in the NDP having limited success in terms of addressing climate change.

The KwaZulu-Natal Provincial Growth and Development Strategy (PGDS) is a notable response document to climate change for the Province. The PGDS (2016: 30) argues that the environmental sustainability of the Province is challenged, due to erratic and severe weather conditions such as droughts, flooding, severe storms, and poor land-use practices. This requires a great deal of attention to enhance the resilience of ecosystem services, expand the application of green technologies, as well as adapt and respond to climate change (PGDS, 1016: 37). However, one would argue that the expansion of green technologies is ignorant of the varying realities of communities.

\footnotetext{
2 This includes coal mining, which challenges mitigation strategies to reduce the implications of climate change.
}

\subsection{Vulnerability}

Vulnerability is a concept that has a wide range of research contexts. Its roots are found in natural hazards and geographic research, but a number of researchers use the concept in disaster management, climate change, adaptation, and development (Füssel, 2005: 1; Zarafashani, Sharafi, Azadi \& Van Passel, 2016: 3). The cross-cutting nature of the climate change problem requires collaboration from various disciplines such as disaster management, economics, policy, and risk assessment. The Intergovernmental Panel on Climate Change (IPCC) links climate change with vulnerability and mentions that the vulnerability of a specific area is reliant on its economic resources, and it is based on the idea that poverty limits an area's coping capacity (Niang, Osman-Elasha, Githeko, Yanda, Medany \& Vogel, 2008: 6; Patnaik \& Narayanan, 2009: 3). Using Raemaekers and Sowman's (2015: 5) vulnerability components, Figure 1 represents vulnerability, which is the function of the character, magnitude, rate of climate change and variation to which a system is exposed, its sensitivity, and its adaptive capacity (Brooks, 2003: 3; Cuevas, 2011: 35; Giordano, 2014). Vulnerability consists of three elements, namely exposure ${ }^{3}$ sensitivity, ${ }^{4}$ and adaptive capacity ${ }^{5}$ (see Figure 1).

3 Exposure denotes the "presence of species, ecosystems, environmental functions, livelihoods, resources, social, economic or cultural assets that could be adversely affected by a climate-induced hazard" (IPCC, 2018: 5)

4 Sensitivity refers to the degree to which a system or species is affected either beneficially or adversely by climate change or variability (IPCC, 2007: 6).

5 Adaptive capacity is defined as the "potential, capability, or ability of a system to adapt to climate change stimuli or their effects of impacts (IPCC, 2001a: 6). It is the capacity of communities using resources, skills, information technology, services and institutions to cope with climate-related hazards and adapt to climate change, in order to anticipate, cope with, prepare and recover from climatic hazards (Smit \& Pilifosova, 2001: 893; Grothmann, Grecksch, Winges \& Siebenhüner, 2013: 3371; Shah, Dulal \& Awojobi, 2020: 221). 


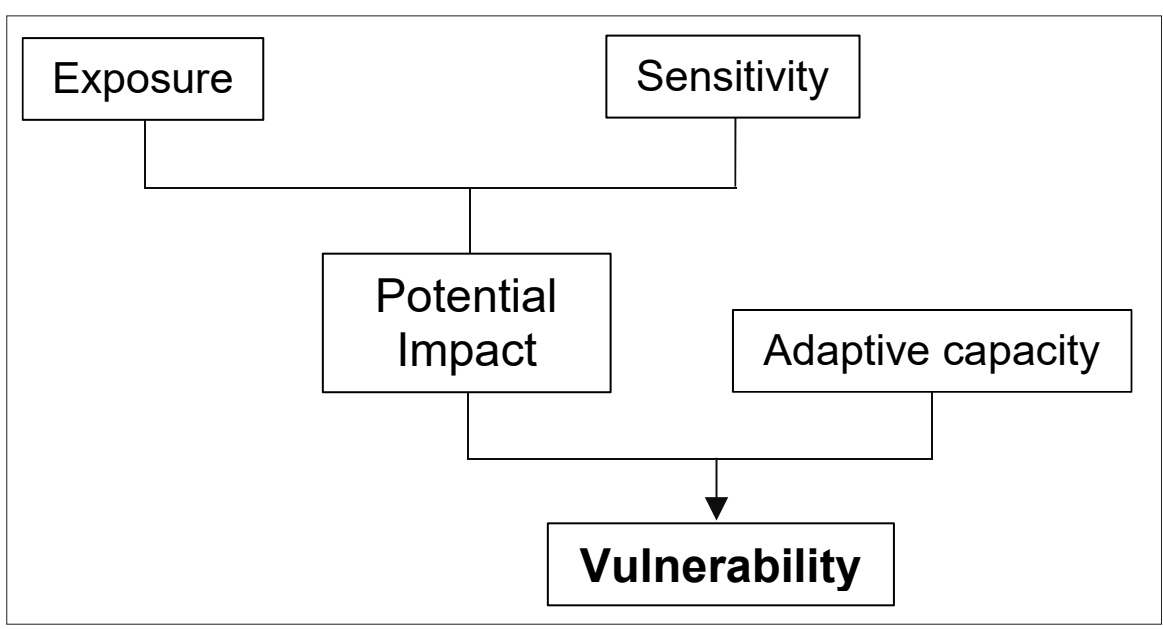

Figure 1: Vulnerability components

Source: $\quad$ Author's own, 2020

Vulnerability is categorised into biophysical and socio-economic categories. The biophysical is rooted in the physical state of people and in those categories that are at risk; these include infrastructure, proximity, and location (Salami, Von Meding \& Giggins, 2017: 3; Mavhura, 2019: 73). The socio-economic is based on the specific population that will be affected by climate change and variability (Esperón-Rodríguez, Bonifacio-Bautista \& Barradas, 2016: 147). The socio-economic status of people determines the intensity of the impact. The following vulnerable sectors have been evaluated to determine the impacts of climate change. These will be discussed in terms of the biophysical and socio-economic aspects.

The biophysical aspects will evaluate climate change impacts and vulnerability in four sectors, namely biodiversity, water, agriculture, and food security. Changes in temperature, rising carbon dioxide levels, and the changing rainfall patterns result in a shift of the country's biomes, and this has implications for species diversity, ecosystem processes, and services (Ziervogel et al., 2014: 608; NCCRWP, 2011: 20). This includes shifting habitat ranges and species distribution, altering life cycles, changes in migration patterns, changes in abundance, changes in frequency, and severity of pests and diseases outbreaks their distribution, spatial shift in ideal growing regions and reduced yield (DoEA, 2013). The under-resourced, small-scale and subsistence farmers are highly vulnerable to the impacts of climate change, which leads to food insecurity and higher levels of poverty. Maize, a major subsistence crop, could see the yields being reduced as much as $10 \%$ to $20 \%$ and most of the areas will become unsuitable for maize production (DoEA, 2013).

The socio-economic aspects will evaluate climate change impacts and vulnerability in two sectors, namely tourism and poverty. Climate change is expected to have significant implications on tourism that will have associated impacts on livelihoods in terms of employment, incomes, and an increase in the cost of living (SDF, 2019: 48). This is a concern, especially in areas such as uMkhanyakude that are dependent on the tourism sector to economically uplift communities. The impoverished would become more vulnerable as they would require making means to survive below the poverty line. South Africa's adaptive capacity is predisposed by social factors such as unemployment, and poverty and by housing typology such as informal settlements, which are highly susceptible to extreme weather events. Vulnerability is, therefore, not static, as institutions, individuals and communities including economic sectors are affected differently, irrespective of previously mentioned social factors (Mambo, 2017: 2). Hence, vulnerability is content and location specific and should be assessed, taking account of the natural and socio-economic factors of that specific location.

\subsection{Adaptation}

Adaptation refers to the adjustment in natural or human systems in response to actual or expected climatic stimuli or their effects, which moderates harm or exploits beneficial opportunities. Various types of adaptation can be distinguished, including anticipatory and reactive adaptation, private 
and public adaptation, as well as autonomous and planned adaptation (IPCC, 2001b: 6). Further, it also refers to actions that countries and communities implement to adjust to social and environmental impacts such as climate change. Adaptation has three objectives, namely to reduce exposure to the risk of damage; to develop the capacity to cope with unavoidable damage, and to take advantage of new opportunities (Akinnagbe \& Irohibe, 2014: 408). Although there are noted efforts to create an adaptation planning framework by IPCC, there is no internationally agreed methodology for creating adaptation strategies. Most of the adaptation strategies that have been created and characterised by adjustments have been done by communities (Ziervogel \& Zermoglio, 2009: 134; Antwi-Agyei, Dougill \& Stringer, 2013: 12). This has been due to the fact that the impacts of climate change are localised, due to variances in demographics and economic complexities (Kihila, 2018: 3). In addition, this indicates geographical limits in the pertinence of some of these strategies. Consequently, the adaptation strategies created in relation to climate change impacts are defined in their own contexts (see Table 1).

\section{STUDY AREA}

UMkhanyakude District Municipality is the northernmost of the 11 district municipalities in KwaZulu-Natal (see Figure 2). At $12,818 \mathrm{~km}^{2}$ and with a population of 689,090 , uMkhanyakude District Municipality is the second largest district in the Province, in terms of size after its neighbouring district, Zululand District Municipality (IDP, 2018/2019: 18). It is located around latitude -27.622S and longitude 32.014E (IDP, 2018/2019: 18). It is a peri-urban and predominantly rural district with a dependency

Table 1: Adaptation responses to climate change

\begin{tabular}{|c|c|}
\hline Sector & Adaptation strategies \\
\hline Biodiversity & $\begin{array}{l}\text { Strengthen institutional arrangements to further develop expanded public works } \\
\text { programmes (EPWP) for building ecosystem and community resilience through } \\
\text { the restoration of wetlands, controlling wildfires, removing alien plants and } \\
\text { other sustainability programmes. These approaches can be included at local } \\
\text { government (DoEA, 2016: 58) }\end{array}$ \\
\hline Water & $\begin{array}{l}\text { Adopt a low or no-regrets approach concerning decisions about water } \\
\text { infrastructure, in the context of climate change, to balance socio-economic } \\
\text { considerations with ecological considerations (DoEA, 2016: 50) }\end{array}$ \\
\hline \multicolumn{2}{|l|}{ Agriculture } \\
\hline Crop management & $\begin{array}{l}\text { Crop diversification, intercropping, crop rotation, increase of farm size, use of } \\
\text { organic/chemical fertiliser, drought-tolerant/early maturing varieties, change timing } \\
\text { of land preparation/planting, crop irrigation, grain storage, sharecropping. Climate- } \\
\text { smart agriculture, extension support (Kihila, 2018: 4-5; Wiederkehr, Beckmann \& } \\
\text { Hermans, 2018: 7) }\end{array}$ \\
\hline $\begin{array}{l}\text { Soil and water } \\
\text { management }\end{array}$ & $\begin{array}{l}\text { Erosion control, terracing, drainage ditches, ridges, micro-catchments, ploughing, } \\
\text { stone bunds, mulching, digging of boreholes and wells, construction of small } \\
\text { dams, water storage, drinking water treatment (Wiederkehr et al., 2018: 7) }\end{array}$ \\
\hline Early warning system & $\begin{array}{l}\text { Provision of seasonal forecast or community weather monitoring station (DoEA, } \\
\text { 2018: 24) }\end{array}$ \\
\hline Human health & $\begin{array}{l}\text { Ensure provision of clean sanitation and freshwater services to reduce water- } \\
\text { borne diseases. Continuous water quality tests should be done frequently to } \\
\text { monitor and manage the spread of water-borne diseases. Manage the incidence } \\
\text { and spread of climate-related water-borne disease vectors (DoEA, 2016: 61) }\end{array}$ \\
\hline $\begin{array}{l}\text { Indigenous } \\
\text { knowledge }\end{array}$ & $\begin{array}{l}\text { Encourage the local people to practise and share their indigenous knowledge } \\
\text { information (Kihila, 2018: 2) }\end{array}$ \\
\hline \multicolumn{2}{|c|}{ Other adaptation strategies } \\
\hline Social networks & $\begin{array}{l}\text { Rely on support from friends or relatives, receive remittances (Wiederkehr et al., } \\
\text { 2018: 7) }\end{array}$ \\
\hline Income diversification & $\begin{array}{l}\text { Trading, pottery, tourism, local wage labour, sell bush plants (Wiederkehr et al., } \\
\text { 2018: 7) }\end{array}$ \\
\hline Food provision & $\begin{array}{l}\text { Work for food, eat wild fruits, change diet, reduce food consumption, seek food } \\
\text { aid, buy food, sell assets to buy food, harvest to obtain food, plant food trees, store } \\
\text { food (Wiederkehr et al., 2018: 7) }\end{array}$ \\
\hline
\end{tabular}

Source: DoEA (2016; 2018; 2019); Kihila (2018); Wiederkehr et al. (2018)

ratio of $81.2 \%$. This municipality is regarded as the poorest municipality in KwaZulu-Natal and one of the poorest district municipalities in South Africa (Patrick, 2020: 4).

According to Patrick (2020: 4), the district is one of the most socio-economically deprived district municipality in South Africa, ranking 51 of the 55 most deprived. UMkhanyakude District Municipality is characterised by poor economic development, limited infrastructure, and experiences of poor service delivery (Dlamini, 2018: 51; Mulopo, Kalinda \& Chimbari, 2020: 2). Most of the services in this district are located and distributed in the district's urban areas and this contributes to the inability of the local municipalities ${ }^{6}$ to provide the economic stimuli for the district municipality, in order to break the poverty cycle that is affecting its economic growth and prosperity (Dlamini, 2018: 51).

Poverty has been exacerbated by high illiteracy and lack of growth opportunities within uMkhanyakude. The poverty rate for the district municipality ranges between $72.1 \%$ and $88.6 \%$ of the total population. According to Patrick (2020: 5), over $70 \%$ of the population in uMkhanyakude survives on less than R800 per month and over $83 \%$ of the total households live below the poverty line. Approximately $14 \%$ of the unemployed population within the district has not received formal schooling and a further $17 \%$ only has an elementary level of education (Patrick, 2020: 5). It is noted that the largest percentage of the unemployed population has completed Grade 12 education and a further $30 \%$ have some form of secondary education (IDP, 2018/2019: 76). Only a small percentage of the unemployed population has completed any form of tertiary education. The extent of poverty in the rural areas in uMkhanyakude has forced $95 \%$ of the inhabitants to survive through subsistence farming, grants from the

6 UMhlabuyalingana Municipality (KZ 271), Jozini Municipality (KZ 272), Mtubatuba Municipality (KZ 275) and the Big Five Hlabisa Municipality (KZ 276). 
government as well as remittances from family members working outside the municipality (Dlamini, 2018: 53; SDF, 2019/2020: 45). The main economic sectors in uMkhanyakude are agriculture, tourism, and trade. However, all these sectors have experienced adverse effects, due to the impacts of climate change.

\section{METHODOLOGY}

A qualitative secondary data approach was used to evaluate whether vulnerable communities in uMkhanyakude District Municipality could become resilient to the implications of climate change (Ruggiano \& Perry, 2019: 83). The gathered data included the strategic framework, integrated development plan and related climate change plans from uMkhanyakude District Municipality, as well as relevant journal articles that were accessed through Google Scholar, Scopus and Science Direct. The search criteria included "climate change", "vulnerability", "adaptation", "food security", "agriculture", "water", "biodiversity", "tourism", "poverty" in the topic field of literature, in order to determine the impacts of climate change and their cascading consequences on the biophysical and socio-economic aspects.

The gathered data used content analysis, whereby related climate change data was evaluated to reflect on key aspects such as the biophysical and socio-economic that have been used to determine whether uMkhanyakude could become resilient (Bengtsson, 2016: 8). Therefore, a concise summary of key findings, categorised according to the biophysical and socio-economic aspects (agriculture, water, food security, biodiversity, tourism and poverty) evaluates whether vulnerable communities within the District Municipality could become resilient.

\section{FINDINGS}

\subsection{Biophysical aspects}

\subsubsection{Biodiversity}

According to Hoffman et al. (2019: 5), the main implication of climate change on biodiversity is the decrease in the availability and quantity of suitable habitats, and some ecosystems may expand into new areas, while others may decrease. Consistent with biophysical conditions in uMkhanyakude District Municipality, there has been a loss of high-priority biomes such as

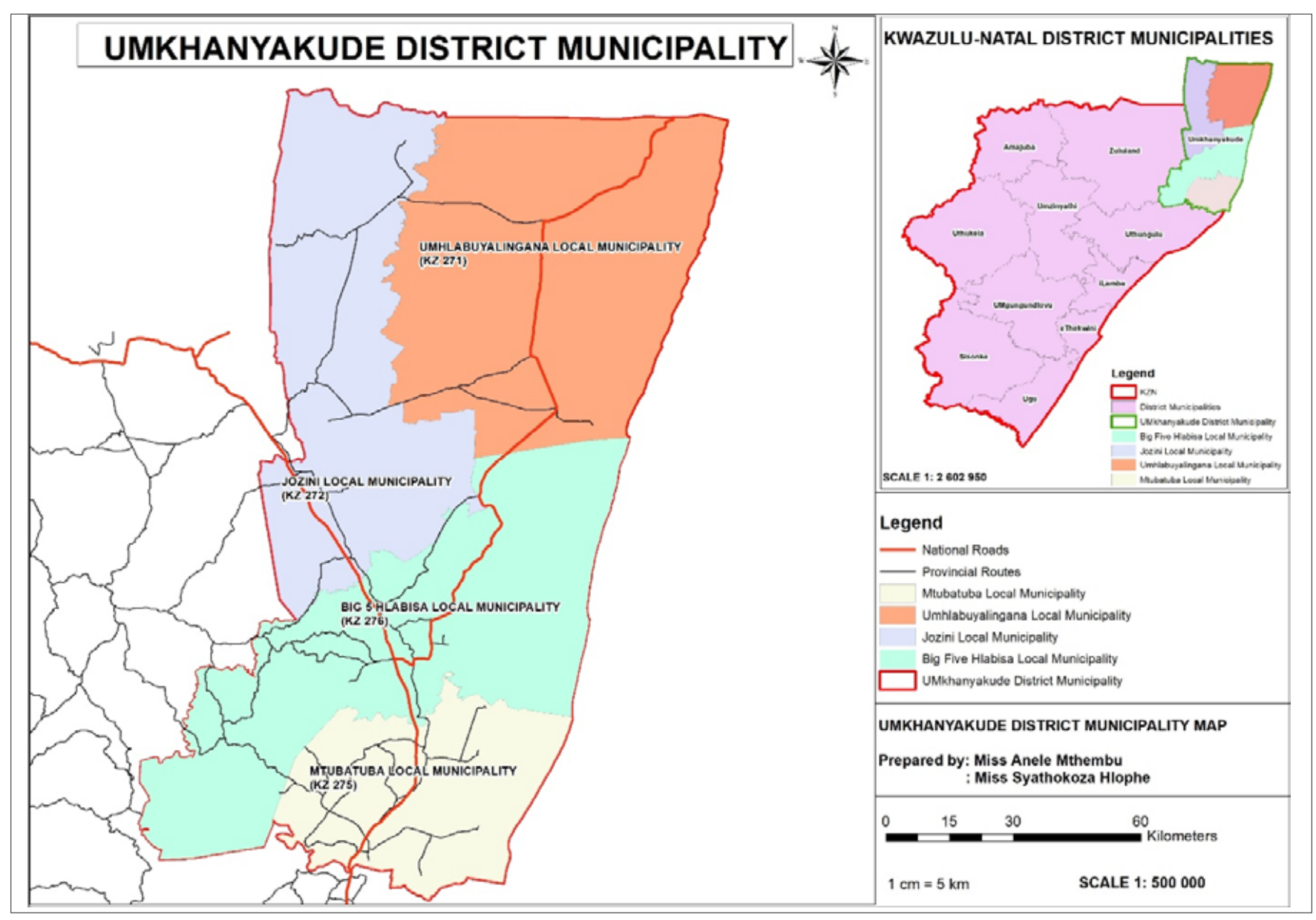

Figure 2: Locality map of uMkhanyakude District Municipality

Source: Author's own (2020) 
grasslands and coastal belts. There has also been an increase in the proliferation of invasive alien species which outcompete indigenous plants (see Table 2) (IDP, 2018/2019: 44).

Table 2: Invasive alien species contained in uMkhanyakude District Municipality

\begin{tabular}{|l|c|}
\hline Invasive alien species & $\begin{array}{c}\text { Condensed } \\
\text { hectares } \mathbf{( H a )}\end{array}$ \\
\hline Chromolaena odorata & 31,522 \\
\hline Eucalyptus spp. & 4,314 \\
\hline Lantana camara & 1,538 \\
\hline Psidium guajava & 872 \\
\hline Pinus spp. & 315 \\
\hline Melia azedarach & 176 \\
\hline Solanum mauritianum & 149 \\
\hline
\end{tabular}

Source: IDP, 2018/2019: 44

It is worth noting that a total of 19 invasive alien species were singled out for eradication, of which five were identified as priority species for immediate attention and eradication, namely Ipomoea carnea subsp., Fistulosa, Pereskia aculeate, Chromolaena odorata, and the Lantana camara (IDP, 2018/2019: 44). According to the IDP (2018/2019: 44), some work is done within the District regarding alien plant control through programmes by the Department of Agriculture and Environmental Affairs, Ezemvelo KwaZulu-Natal Wildlife, iSimangaliso Wetland Park, and the Department of Water and Sanitation.

\subsubsection{Water}

According to the IDP (2018/2019: 82), access to basic water infrastructure remains one of the key challenges within the District. This is supported by the proportion of households that have access to water through regional and local water schemes, being $42 \%$ compared to the provincial figure of $72 \%$ (IDP, 2018/2019: 82). Approximately 30\% of the households utilise untreated sources of water directly from dams, springs or rivers, and this is alarming as the provincial total is only $13 \%$.

According to Dlamini (2018: 58), the District falls within the Mfolozi/ Pongolo primary catchment area, one of the District's main catchment area that is shared with neighbouring countries Swaziland and Mozambique, and the bordering municipalities. The transboundary nature of the catchment area and the diverse aquatic and wetland inhabitants of the water system rely on sustainable management of the system's resources (Dlamini, 2018: 57). These features have contributed significantly towards the main economic sectors; however, the unstable supply of water has compromised most if not all of these sectors.

Jozini Local Municipality is home to one of the largest dams in KwaZuluNatal, the Jozini Dam, which was recognised, near the town of Jozini in 1973, as part of the PongolapoortMakhathini flats Government Water Scheme (GWS) (Dlamini, 2018: 58).
The Jozini Dam was primarily built for controlling flooding and storing water for irrigation of agriculture. While this is one of the largest dams in the country, it also has the potential to assist in terms of supplying water to the District (see Figure 3). Unfortunately, due to the historical development of this dam and private ownership rights, it has contributed less to the inhabitants who need water for subsistence farming and consumption (Dlamini, 2018: 58).

Over the years, other water sources within the District have experienced a considerable decline in water quality, as a result of sugarcane farming and the seepage of sulphate from adjacent mines (Dlamini, 2018: 61). Other factors include the Mfolozi River which has less water during

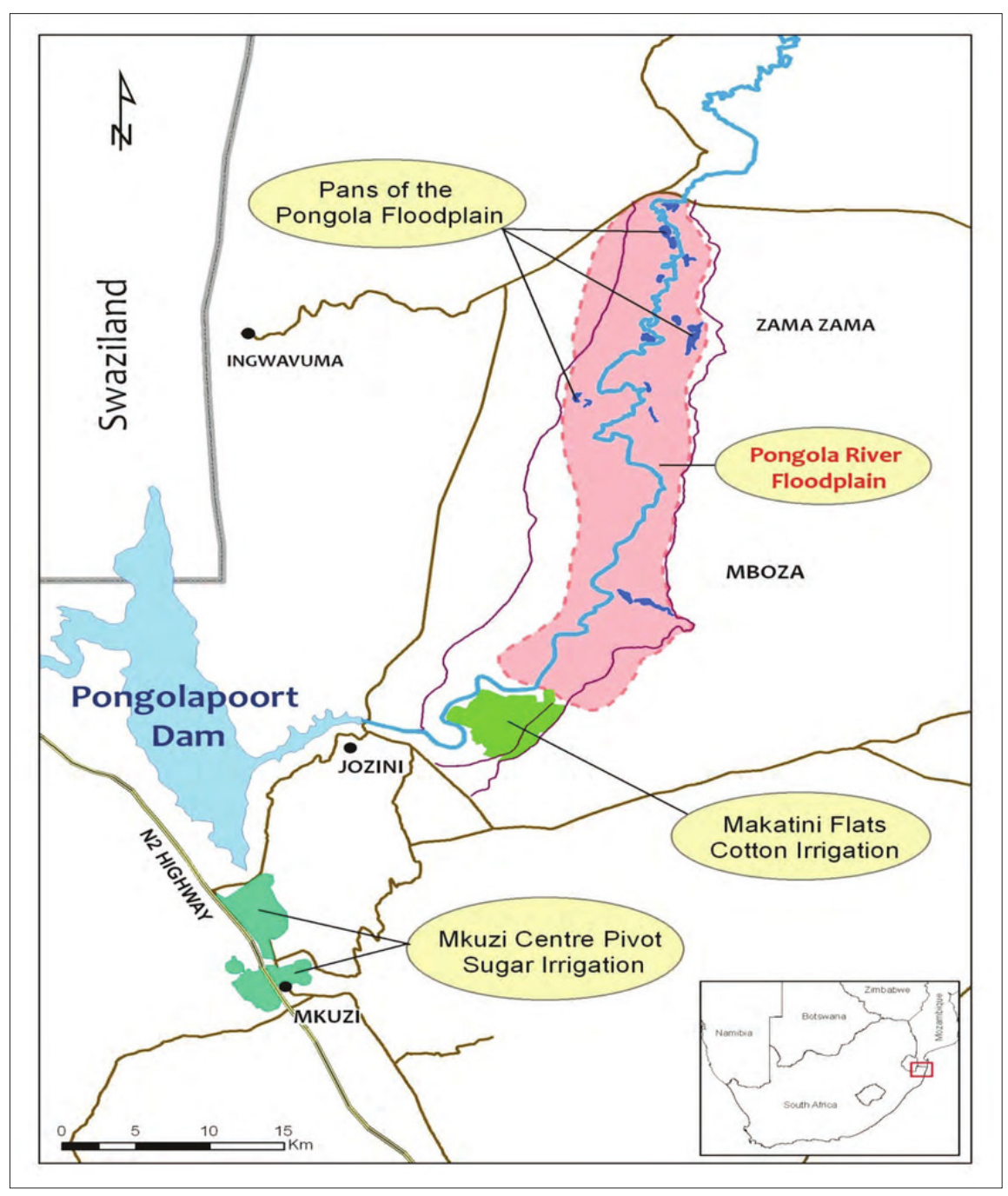

Figure 3: Pongolapoort/Jozini Dam

Source: Dlamini, 2018: 59 
dry seasons. This has contributed to the high silt abstraction levels.

Furthermore, the deterioration of water quality has led to a lack of drinkable water and water cleanliness in the District, as per the waterquality standards. The increase in water-related natural disasters means that less water is available to dilute wastewater discharges and irrigation return flows to rivers, and the uMfolozi and Phongolo rivers are dry (SDF, 2019: 48). In terms of availability, less water is available for drinking and irrigation, and the increase in drought events results in less water being available for domestic use. The Jozini, Hluhluwe and uMfolozi rivers have low water levels (Gwala, 2018: 48).

Figure 4 highlights the average rainfall over a period of time in uMkhanyakude, in accordance with 4 water features, using the Standardised Precipitation Index (SPI) measured in millimetres. According to Gwala (2018: 48), the Mbhuzana river experienced the highest rainfall in 1996 with 1 millimetre and the lowest rainfall in 2015 with -2.5 millimetres. The Riverview river experienced its highest rainfall in 2000 with 2 millimetres and the lowest in 2016 with -3 millimetres. The Pongolapoort Dam experienced its highest rainfall in 2000 with 2 millimetres and the lowest in 2003 with 1.5 millimetres. The Ingwavuma Manguzi river experienced its highest rainfall in 2000 with 1.5 millimetres and its lowest in 2016 with -4 millimetres (Gwala, 2018: 49). SPI drought categories indicate that between 0 to -0.99 of the drought category is mild drought; -1 to -1.49 is moderate drought; -1.5 to -1.99 is severe drought, and -2.00 or less is extreme drought. Figure 4 shows that the extreme drought years were between 2015 and 2016 for Mbhuzana and Ingwavuma Manguzi, respectively.

To address water quality, waterrelated infrastructure and climate change, uMkhanyakude developed a Water Master Plan that was adopted by the Council in 2017. It revealed that most of the existing infrastructure is in a state of disrepair, due to years of poor maintenance and negligence (IDP, 2018/2019: 125). The lack of maintenance of the existing infrastructure has given rise to high maintenance backlogs, resulting in limited water supplies for most of the communities. The Plan identifies the maintenance and upgrade requirements for the district, which compete for limited fiscal resources with new infrastructure meant for first time access to water resources.

\subsubsection{Agriculture}

Agriculture is considered to be one of the cornerstones of the District's economic development. A substantial portion of land in the District, which is predominantly located on the eastern part of uMkhanyakude consists of high agricultural potential (see Figure 5). Approximately $20 \%$ of the District is considered to have high potential agricultural activities, with $52 \%$ considered as having medium

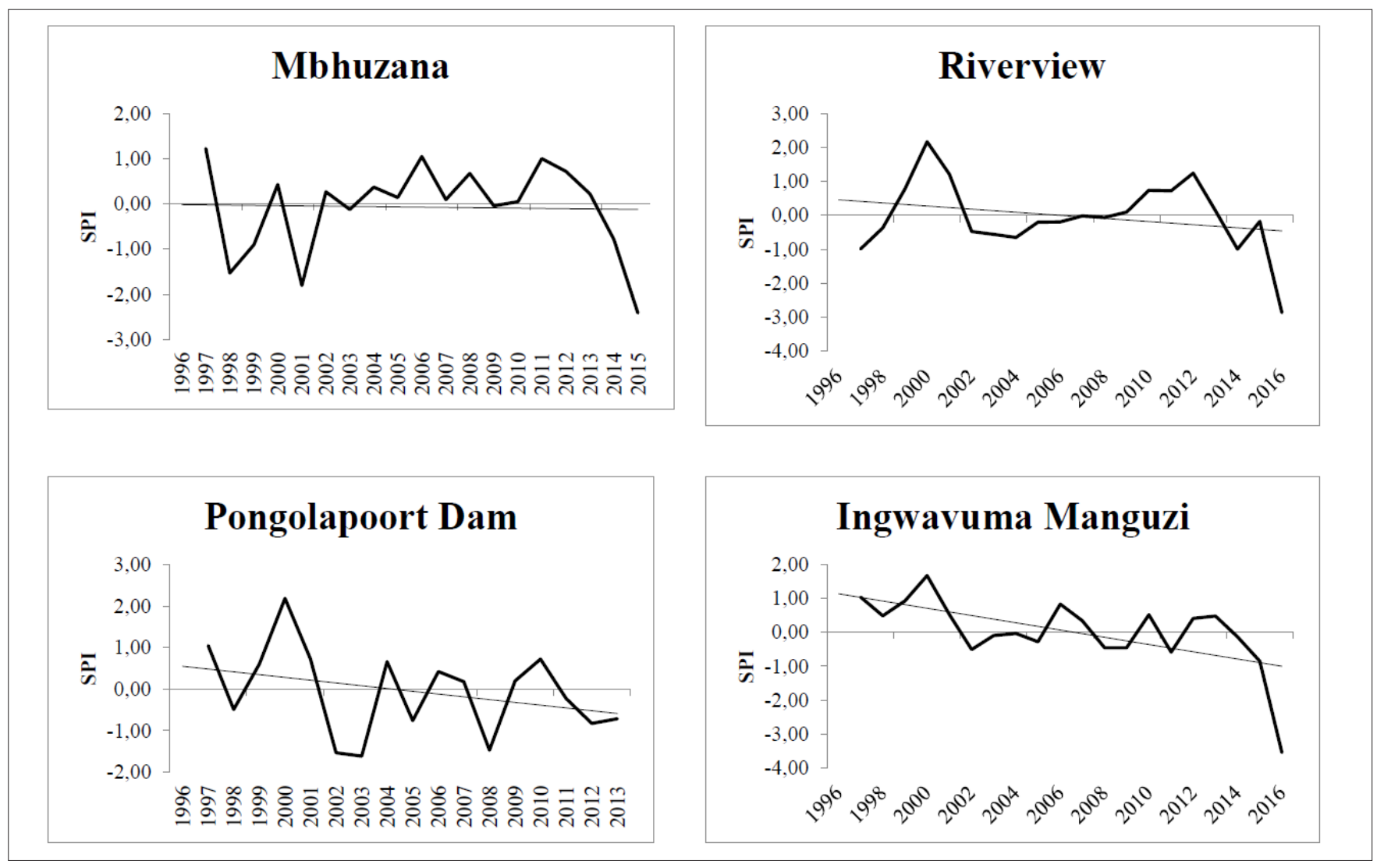

Figure 4: The severity of drought for Mbhuzana river, Riverview river, Pongolapoort Dam and Ingwavuma Manguzi river using the Standardised Precipitation Index (Gwala, 2018: 50) 
potential (IDP, 2018/2019: 67).

It is noted that land with high

agricultural potential is under threat

from unsustainable land uses, poor

agricultural practices, and land

reform. This land requires suitable protection for potential commercial agricultural uses in the future.
According to the IDP (2018/2019: 41), nearly $95 \%$ of the uMkhanyakude's population are rural dwellers, of whom most of the households rely at least partly on subsistence agriculture to meet their food requirements.

Big Five Hlabisa is characterised by commercial and subsistence agriculture, which is most widespread in the old Hlabisa municipal side covering most of the area. The Big Five False Bay Municipality is characterised by both commercial and subsistence agriculture around Hluhluwe (SDF, 2019: 45).

UMhlabuyalingana is bordered by the Pongola River in the west, which incorporates the Pongola Floodplains and the Makhathini Flats that contain

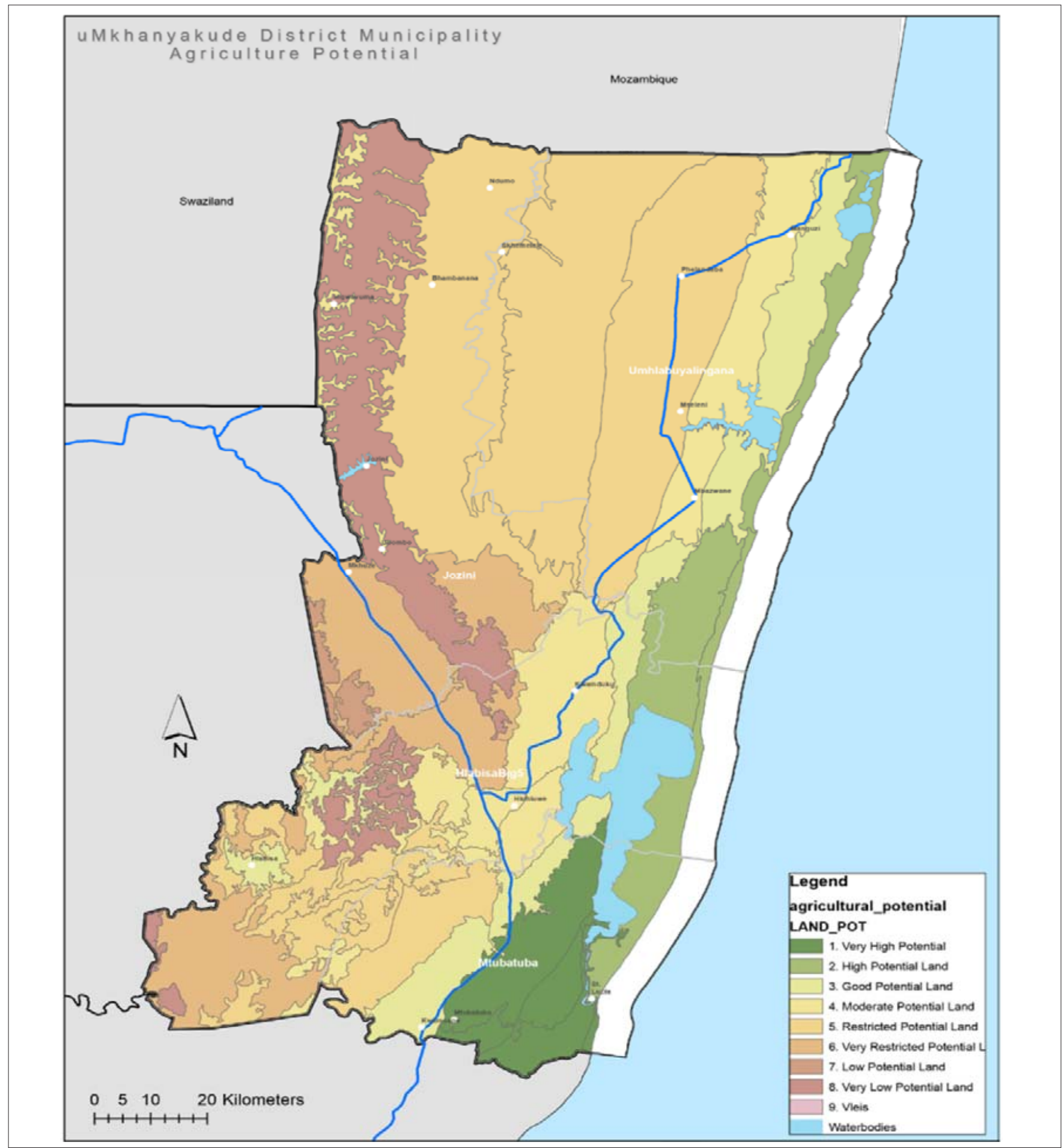

Figure 5: Agricultural potential in uMkhanyakude District Municipality

Source: IDP, 2018/2019: 70 
formal and irrigated croplands (IDP, 2018/2019: 68). Irregular subsistence agriculture occurs within the central and eastern areas, and this is partially due to the general lack of water resources, which compromises permanent water for irrigation of crops. Another contributing factor is the poorly drained area. The reason why the area is mainly unsuitable for agriculture is due to the great extent to which the municipality is situated in a near natural ecological state (IDP, 2018/2019: 68).

Mtubatuba has a very high agricultural potential, and it is the least rural municipal area of uMkhanyakude. According to the IDP (2018/2019: 68), the expansion of the iSimangaliso Wetland Park has meant that there is competition for land resources in Mtubatuba, especially in the southern regions. To protect commercial agricultural activities and forestry, the municipality has endorsed its urban edge development strategy to promote sustainable development.

Sugarcane is the dominant commercial crop in the District and has had an impact on the local watercourses. Further, sugarcane farming practices tend to encroach on the riparian parts of rivers which has a negative impact. The high volumes of irrigation water needed means that the watercourses only receive a substantial amount of agricultural runoff (IDP, 2018/2019: 68).

\subsubsection{Food security}

Climate change projections suggest that rain-fed agriculture in uMkhanyakude is likely to be negatively affected, due to lower annual rainfall, high temperatures, increased hydrological risk, increased rainfall variability, drying of top soils, less water in the soil for irrigating plants, and increased irrigation needs. For that reason, this forms the basis for small-holder agriculture. UMkhanyakude has approximately $20 \%$ of land that has high agricultural potential. Unfortunately, infrastructural backlogs, climaterelated impacts on water resources as well as agricultural practices that are unsustainable and have negative impacts have adverse impacts on food security and livelihoods (IDP, 2018/2019: 41). There are no statistics to indicate how many households are at risk of food insecurity or findings to depict future trends in terms of food security.

\subsection{Socio-economic aspects}

\subsubsection{Tourism}

According to the IDP (2018/2019: 145), uMkhanyakude District Municipality has one of the best climatic conditions in KwaZulu-Natal and South Africa and contributes significantly towards tourism. This entails warm weather, which is conducive for renewable energy generation. However, climate change is projected to have a significant impact on the tourism sector, with resultant impacts on livelihoods in uMkhanyakude. A rise in sea level and loss of biodiversity are projected to impact on the tourism sector, since uMkhanyakude has some of the most pristine dune environments in the world, and their erosion would be a significant loss in terms of tourism and livelihoods. Consequently, it is worth noting that it is not possible to quantify the impacts on tourism and livelihoods, as an outcome of the loss of biodiversity and changes in sea level (SDF, 2019: 48).

\subsubsection{Poverty}

Social inequalities such as lack of access to basic services, income, urban-bias, spatial and poverty are most prevalent in the rural areas, and increase the individuals' exposure to climate hazards, increase the susceptibility to damage caused by climatic hazards, and decrease the ability to cope with and recover from the damage (UNICEF, 2011; Cardona, Van Aalyst, Birkmann, Fordham, McGregor \& Perez et al., 2012; Islam \& Winkel, 2017; Hallegatte, Voqt-Schilb, Rozenberg, Bangalore \& Baudet, 2020).

According to Patrick (2020: 5), the poverty rate of the District is extremely high and ranges between $72.1 \%$ and $88.6 \%$ of the total population; high illiteracy rates have been identified to increase levels of poverty. According to the IDP (2018/2019: 76), the completion of secondary school education does not guarantee any form of formal employment, as 35\% of the unemployed population has a secondary school qualification (see Figure 6). Figure 6 highlights that a tertiary education or a skills-based qualification guarantees, to some extent, employment to contribute towards transforming the District.

In uMkhanyakude, approximately $70 \%$ of the unemployed population is younger than 35 years of age, of whom $35.2 \%$ is younger than 25 years of age, and $34.9 \%$ is aged between 25 and 34 years (IDP, 2018/2019: 75). The vast majority of the unemployed population younger than 25 years was under the Hlabisa Local Municipality during the 2011 STATS census; this local municipality has since been merged with Big Five False Bay Municipality. This means that the Big Five Hlabisa Municipality has the highest rate of unemployment of individuals under the age of 25 years.

Table 3 highlights that uMkhanyakude District Municipality has a low adaptive capacity to the implications of climate change. This is projected to result in poor and rural communities being increasingly vulnerable to the impacts of climate change.

\section{CONCLUSION}

This article evaluated whether vulnerable communities in uMkhanyakude District Municipality, which is predominantly rural and regarded as the poorest district municipality in KwaZulu-Natal, could become resilient to the implications of climate change. The focus was on the implications of climate change in uMkhanyakude District Municipality, using the vulnerability categories of biophysical and socio-economic. Climate change remains one of the biggest environmental challenges in South Africa, with severe implications for socio-economic livelihoods of the rural people. It is evident 
that climate change is a natural phenomenon. However, the climate is changing at abnormal rates, due to the interference of human activities on climatic variables.

The findings revealed that, in terms of the biophysical aspects of uMkhanyakude, the District's invasive alien species compromise water security and ecosystem services since they compete with crops. This impacts on food security. Findings further revealed that, although climate change mainly impacts on water resources within the District, infrastructural backlogs due to poor maintenance and negligence also impact on the communities' access to water resources. Although agriculture is considered one of the cornerstones of the District's economic development, tourism and trade industries contribute significantly towards the overall functioning of the Municipality. Climate change impacts on agriculture, while unsustainable land management causes a decline in food security, poor agricultural yields and crop production as well as the loss of income for small-holder farmers. This compromises the livelihoods of communities that are dependent on rain-fed agriculture.

Vulnerable communities in uMkhanyakude District Municipality have a low adaptive capacity, which limits their ability to become resilient to the implications of climate change. Further, due to their disaster management unit operating in a silo and lacking bottom-up participation of vulnerable communities, the importance of indigenous knowledge has been overlooked when it comes to drafting plans to address climate change and natural disasters. Until there is a shift in terms of paradigms, uMkhanyakude will continue to face the impacts of climate change and their cascading consequences, unless there is a systematic, bottom-up and proactive initiative that will consider grassroot participation, in order to become resilient. This research thus shows that uMkhanyakude District Municipality is not resilient to the implications of climate change, due

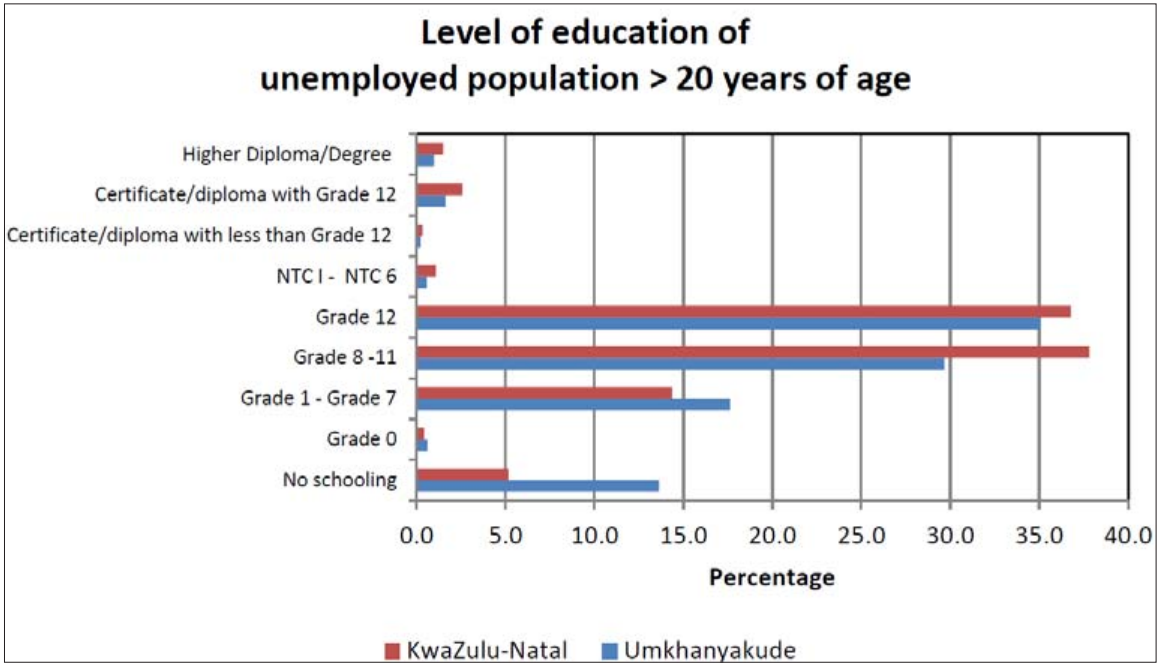

Figure 6: Level of education of unemployed population in uMkhanyakude District Municipality

Source: IDP, 2018/2019: 77

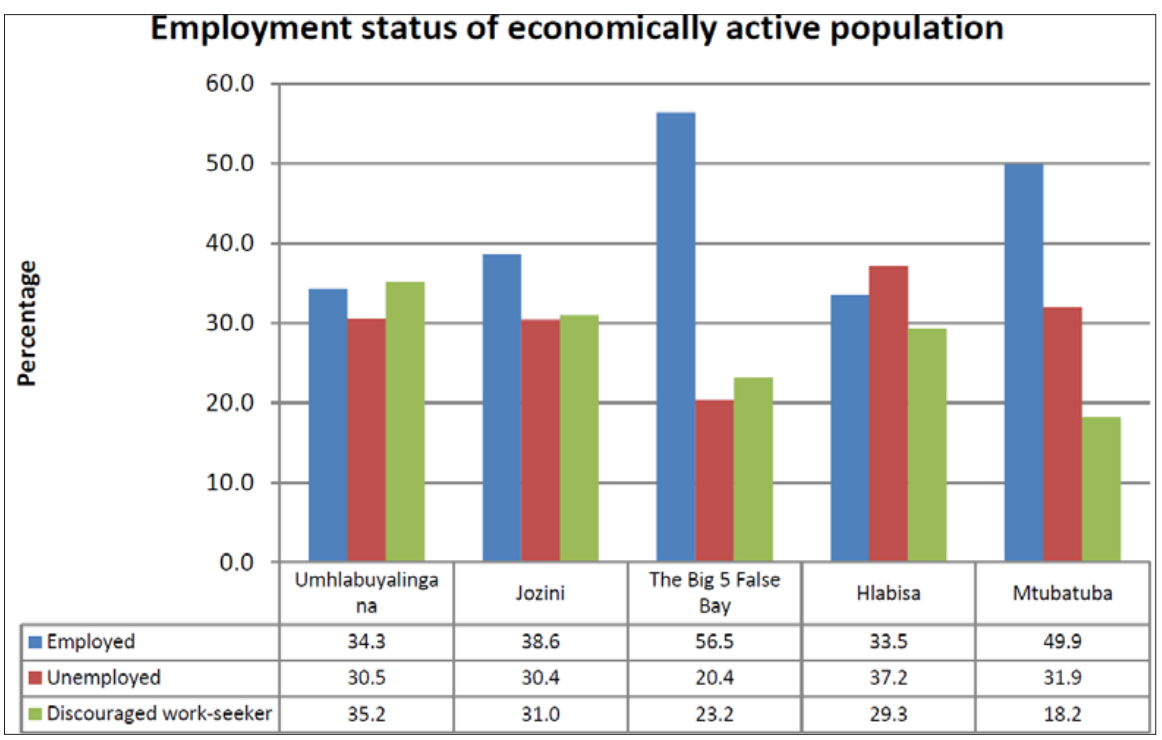

Figure 7: Employment status of economically active population in uMkhanyakude District Municipality

Source: IDP, 2018/2019: 75

Table 3: Vulnerable sectors in uMkhanyakude District Municipality

\begin{tabular}{|l|l|l|l|l|}
\hline \multicolumn{1}{|c|}{ Sector } & \multicolumn{1}{|c|}{ Sector description } & \multicolumn{1}{|c|}{ Exposure } & \multicolumn{1}{c|}{ Sensitivity } & \multicolumn{1}{c|}{$\begin{array}{c}\text { Adaptive } \\
\text { capacity }\end{array}$} \\
\hline Water resources & $\begin{array}{l}\text { Less water available for irrigation and } \\
\text { drinking. }\end{array}$ & Yes & High & Low \\
\hline Biodiversity & $\begin{array}{l}\text { Loss of priority wetlands and river } \\
\text { ecosystems. }\end{array}$ & Yes & High & Low \\
\hline $\begin{array}{l}\text { Agriculture and } \\
\text { food security }\end{array}$ & $\begin{array}{l}\text { Increased exposure to pests such as } \\
\text { eldana, chilo and codling moth } \\
\text { Change in grain (maize, wheat } \\
\text { and barley) }\end{array}$ & Yes & High & Low \\
\hline Human health & $\begin{array}{l}\text { Increased water-borne and } \\
\text { communicable diseases (typhoid, fever, } \\
\text { cholera, and hepatitis) }\end{array}$ & Yes & High & Low \\
\hline
\end{tabular}

Source: uMkhanyakude Climate Change Vulnerability Assessment and Response Plan, 2019: 7-8 
to top-down approaches and reactive strategies to climate change.

\section{RECOMMENDATIONS}

The use of indigenous knowledge is significant in climate change adaptation and building resilience, and this is recognised through enabling indigenous knowledge in the design and implementation of projects sustainably (Kihila, 2018: 2). Although indigenous communities are localised, they have emancipatory knowledge that could be considered and used to improve the resilience to climate change. Participatory governance could also assist in finding solutions that consider the environmental characteristics of a region, which could make the solutions manageable and meaningful. Due to their comprehension on complex social-ecological systems, they make it easier for the development of useful and effective coping and adaptation strategies (Adams et al., 2017: 57).

One of the management priorities for combating climate change is to create awareness (SDF, 2019/2020: 45); however, one may argue that creating awareness is not sufficient to building resilience and addressing the implications of climate change. Hence, it is recommended that improving resilience to climate change could implement sustainable development and improve coping capacity. Planning for adaptation must begin with an assessment of the vulnerable communities including their coping capacities and the realisation that adaptation strategies are susceptible to change, and they are not universal. This may be more beneficial than solely creating awareness to climate change.

A climate change strategy was recommended in the uMkhanyakude District Municipality (IDP Review 2018/2019). However, Ziervogel et al. (2014: 613) argue that there are institutional barriers in addressing climate change. These institutional barriers include a lack of capacity both in terms of communities and technical rationality, high turnover of staff in government departments, limited comprehension of, and expertise in tackling climate-related issues, climate change being regarded as a development challenge instead of an environmental challenge that affects livelihoods. These barriers may take some time to resolve. The implications of climate change continue to affect communities. Therefore, in the case of uMkhanyakude District Municipality, while institutional barriers are considered, an implementation-oriented process that will take place in a systematic, proactive and bottom-up manner, needs to commence to ensure that vulnerable communities have access to bulk infrastructure.

Lastly, conducting social impact assessments (SIAs) would be beneficial when systematic, bottomup and proactive measures are in place within the district municipality. This would assist in terms of assessing social consequences that are likely to follow from specific policy actions or project development, especially in the context of appropriate national or provincial environmental policy legislation (Esteves, Franks \& Vanclay, 2012). Conducting social impact assessments would prevent unnecessary environmental consequences of development to the most vulnerable social groups and play a significant role towards sustainable development.

\section{REFERENCES}

ADAMS, V.M., ÁLVAREZ-ROMERO, J.G., CAPON, S.J., CROWLEY, G.M., DALE, A.P., KENNARD, M.J., DOUGLAS, M.M. \& PRESSEY,

R.L. 2017. Making time for space: The critical role of spatial planning in adapting natural resource management to climate change. Environmental Science \& Policy, 74(C), pp. 57-67. https://doi.org/10.1016/j. envsci.2017.05.003
AKINNAGBE, O.M. \& IROHIBE, I.J. 2014. Agricultural adaptation strategies to climate change impacts in Africa: A review. Bangladesh Journal of Agricultural Research, 39(3), pp. 407418. https://doi.org/10.3329/bjar. v39i3.21984

ANTWI-AGYEI, P., DOUGILL, A.J. \& STRINGER, L.C. 2013. Barriers to climate change adaptation in sub-Saharan Africa: Evidence from northeast Ghana and systematic literature review. Climate and Development, 7(4), pp. 297-309. https://doi.org/10.1080/17565529.2014 .951013

AVERCHENKOVA, A., GANNON, K.E. \& CURRAN, P. 2019. Governance of climate change policy: A case study of South Africa. London: Grantham Research Institute on Climate Change and the Environment and Centre for Climate Change Economics and Policy, London School of Economics and Political Science.

BAUDOIN, M.A., VOGEL, C., NORTJE, K. \& NAIK, M. 2017. Living with drought in South Africa: Lessons learnt from the recent El Niño drought period. International Journal of Disaster Risk Reduction, vol. 23, pp. 128-137. https:// doi.org/10.1016/j.ijdrr.2017.05.005

BENGTSSON, M. 2016. How to plan and perform a qualitative study using content analysis. Nursing Plus Open, vol. 2, pp. 8-14. https://doi. org/10.1016/j.npls.2016.01.001

BROOKS, N. 2003. Vulnerability, risk and adaptation: A conceptual framework. Tyndall Centre for Climate Change Research Working Paper, 38(38), pp. 1-16.

CARDONA, O.D., VAN AALST, M.K., BIRKMANN, J., FORDHAM, M., MCGREGOR, G. \& PEREZ, R. et al. 2012. Determinants of risk: Exposure and vulnerability. In: Field, C.B., Barros, V., Stocker, T.F. et al. (Eds). Managing the risks of extreme events and disasters to advance climate change adaptation. A special report of working groups $i$ and ii of the Intergovernmental Panel on Climate Change (IPCC). Cambridge, UK: Cambridge University Press, pp. 65-108.

CONWAY, G. 2009. The science of climate change in Africa: Impacts and adaptation. Discussion Paper No. 1. London: Grantham Institute for Climate Change. 
CUEVAS, S.C. 2011. Climate change, vulnerability, and risk linkages. International Journal of Climate Change Strategies and Management, 3(1), pp. 29-60. https://doi. org/10.1108/17568691111107934

DoEA (DEPARTMENT OF ENVIRONMENTAL AFFAIRS). 2013.

Long-term adaptation scenarios

flagship research programme (LTAS) for South Africa. Pretoria: Department of Environmental Affairs.

\section{DoEA (DEPARTMENT OF}

ENVIRONMENTAL AFFAIRS). 2016.

South Africa National Adaptation

Strategy Draft for Comments. [Online]. Available at: <http://www.environment. gov.za/sites/default/files/docs/nas2016. pdf> [Accessed: 29 June 2020].

\section{DoEA (DEPARTMENT OF}

ENVIRONMENTAL AFFAIRS).

2018. South Africa's low emission development strategy 2050. [Online]. Available at: <https://www.environment. gov.za/sites/default/files/strategic _ plans/southafricans_lowemission_ developmentstrategy_dec2018draft. pdf> [Accessed: 13 June 2020].

\section{DoEA (DEPARTMENT OF}

ENVIRONMENTAL AFFAIRS). 2019.

Draft National Climate Change Adaptation Strategy. [Online]. Available at: <https://cer.org.za/wp-content/ uploads/2019/05/DEA-Draft-climatechange-adaptation-strategy.pdf> [Accessed: 30 June 2020].

DE WET, P. 2020. Two years later, SA's drought has just been declared a national emergency - again. [Online]. Available at: <https://www. businessinsider.co.za/south-africasdrought-was-just-declared-a-nationalemergency-2020-3> [Accessed: 1 June 2020].

DLAMINI, S.H. 2018. Assessing the capacity of municipalities for water provision within a rural context: A case study of uMkhanyakude District Municipality, KwaZuluNatal, South Africa. Unpublished Masters dissertation, University of KwaZulu-Natal.

ENQVIST, J.P. \& ZIERVOGEL, G. 2019. Water governance and justice in Cape Town: An overview. Wiley Interdisciplinary Reviews: Water, 6(4), p.e1354. doi: 10.1002/wat2.1354
ESPERÓN-RODRÍGUEZ, M., BONIFACIO-BAUTISTA, M. \& BARRADAS, V.L. 2016. Socioeconomic vulnerability to climate change in the central mountainous region of eastern Mexico. Ambio, 45(2), pp. 146-160. https://doi.org/10.1007/ s13280-015-0690-4

ESTEVES, A.M., FRANKS, D. \& VANCLAY, F. 2012. Social impact assessment: The state of the art. Impact Assessment and Project Appraisal, 30(1), pp. 34-42. https://doi. org/10.1080/14615517.2012.660356

FÜSSEL, H.M. 2005. Vulnerability in climate change research: $A$ comprehensive conceptual framework. Stanford University Paper 6. Breslauer Symposium, University of California.

GBETIBOUO, G.A., RINGLER, C. \& HASSAN, R. 2010. Vulnerability of the South African farming sector to climate change and variability: An indicator approach. Natural Resources Forum, 34(3), pp. 175-187. https://doi. org/10.1111/j.1477-8947.2010.01302.x

GIORDANO, F. 2014. Climate change vulnerability and risk: Key concepts. Roma: Instituto Superiore per la Protezione e la Ricerca Ambientale.

GITZ, V., MEYBECK, A., LIPPER, L., YOUNG, C.D. \& BRAATZ, S. 2016.

Climate change and food security: Risks and responses. Rome: Food and Agriculture Organization of the United Nations (FAO) Report, 110.

GREENPEACE AFRICA. 2015. South Africa's intended nationally determined contribution [Presentation]. Cape Town: Greenpeace Africa.

GROTHMANN, T., GRECKSCH, K., WINGES, M. \& SIEBENHÜNER, B.

2013. Assessing institutional capacities to adapt to climate change: Integrating psychological dimensions in the Adaptive Capacity Wheel. Natural Hazards and Earth System Sciences, 13(12), pp. 3369-3384. https://doi. org/10.5194/nhess-13-3369-2013

GWALA, N. 2018. Mapping and monitoring of agricultural drought across different land uses and land cover in the North-Eastern KwaZulu Natal. Unpublished Masters dissertation, Wits University.
HALLEGATTE, S., VOGT-SCHILB, A., ROZENBERG, J., BANGALORE, M. \& BEAUDET, C. 2020. From poverty to disaster and back: A review of the literature. Economics of Disasters and Climate Change, 4(5), pp. 1-25. https:// doi.org/10.1007/s41885-020-00060-5

HENDERSON, J.V., STOREYGARD, A. \& DEICHMANN, U. 2017. Has climate change driven urbanization in Africa? Journal of Development Economics, vol. $124(\mathrm{C})$, pp. 60-82. https://doi. org/10.1016/j.jdeveco.2016.09.001

HOFFMANN, A.A., RYMER, P.D., BYRNE, M., RUTHROF, K.X., WHINAM, J. \& MCGEOCH, M. et al. 2019. Impacts of recent climate change on terrestrial flora and fauna: Some emerging Australian examples. Austral Ecology, 44(1), pp. 3-27. https://doi. org/10.1111/aec.12674

HUQ, N., HUGÉ, J., BOON, E. \& GAIN, A.K. 2015. Climate change impacts in agricultural communities in rural areas of coastal Bangladesh: A tale of many stories. Sustainability, 7(7), pp. 8437-8460. https://doi.org/10.3390/ su7078437

IDP (INTEGRATED DEVELOPMENT PLAN). UMkhanyakude district municipality review, 2018/2019. [Online]. Available at: <http:// www.kzncogta.gov.za/wp-content/ uploads/2017/07/Umkhanyakude.zip> [Accessed: 22 May 2020].

IPCC (INTERGOVERNMENTAL PANEL ON CLIMATE CHANGE). 2001a. Climate change. The scientific basis. London: Cambridge University Press.

IPCC (INTERGOVERNMENTAL PANEL ON CLIMATE CHANGE). 2001b. Climate Change 2001: Synthesis Report. A Contribution of Working Groups I, II, and III to the Third Assessment Report of the Intergovernmental Panel on Climate Change [Watson, R.T. \& the Core Writing Team (Eds)]. Cambridge, UK: Cambridge University Press, 398 pp.

IPCC (INTERGOVERNMENTAL PANEL ON CLIMATE CHANGE). 2007. Climate Change 2007: Impacts, adaptation and vulnerability: Working group II contributing to the fourth assessment report. [Parry, M., Parry, M.L., Canziani, O., Palutikof, J., Van der Linden, P. \& Hanson, C. (Eds)]. Cambridge, UK: Cambridge University Press. 
IPCC (INTERGOVERNMENTAL

PANEL ON CLIMATE CHANGE). 2018.

Global warming of $1.5^{\circ} \mathrm{C}$. Geneva:

World Meteorological Organization.

ISLAM, N. \& WINKEL, J. 2017. Climate change and social inequality. DESA Working Paper No. 152. ST/ESA/2017/ DWP/152, October. Paper prepared for the World Economic and Social Survey, Department of Economic \& Social Affairs.

KIHILA, J.M. 2018. Indigenous coping and adaptation strategies to climate change of local communities in Tanzania: A review. Climate and Development, 10(5), pp. 406-416. https://doi.org/10.1080/17565529.2017 .1318739

MAMBO, J. 2017. Risk and vulnerability to global and climate change in South Africa. In: Mambo, J. \& Faccer, K. (Eds). South African risk and vulnerability atlas: Understanding the social and environmental implications of global change. $2^{\text {nd }}$ edition. Pretoria: Council for Scientific and Industrial Research (CSIR), pp. 1-6.

MAVHURA, E. 2019. Analysing drivers of vulnerability to flooding: A systems approach. South African Geographical Journal, 101(1), pp. 72-90. https://doi.or g/10.1080/03736245.2018.1541020

MBOW, C., ROSENZWEIG, C., BARIONI, L.G., BENTON, T.G., HERRERO, M. \& KRISHNAPILLAI, M. et al. 2019. Chapter 5: Food security. In: Shukla, P.R., Skea, J. \& Calvo Buendia, E. et al. (Eds). Climate change and land: An IPCC special report on climate change, desertification, land degradation, sustainable land management, food security and greenhouse gas fluxes in terrestrial ecosystems. USA: IPCC, pp. 437-550.

MULOPO, C., KALINDA, C. \& CHIMBARI, M.J. 2020. Contextual and psychosocial factors influencing the use of safe water sources: A case of Madeya Village, uMkhanyakude District, South Africa. International Journal of Environmental Research and Public Health, 17(4), article 1349, pp. 1-11. https://doi.org/10.3390/ ijerph17041349
NATIONAL CLIMATE CHANGE RESPONSE WHITE PAPER. 2011. [Online]. Available at: <environment. gov.za/sites/default/files/legislations/ national_climatechange_response_ whitepaper.pdf> [Accessed: 1 June 2020].

NDP (NATIONAL DEVELOPMENT PLAN). 2012. Our future - Make it work. [Online]. Available at: <https:// www.gov.za/issues/nationaldevelopment-plan-2030> [Accessed: 25 May 2020].

NIANG, I., OSMAN-ELASHA, B., GITHEKO, A., YANDA, P.Z., MEDANY, M. \& VOGEL, A. et al. 2008. Africa climate change 2007: Impacts, adaptation and vulnerability. London: Cambridge University Press.

PATNAIK, U. \& NARAYANAN, K. 2009. Vulnerability and climate change: An analysis of the eastern coastal districts of India. Munich, Germany: MPRA.

PATRICK, H.O. 2020. Climate change, water security, and conflict potentials in South Africa: Assessing conflict and coping strategies in rural South Africa. In: Filho, W.L., Luetz, L.M. \& Ayal, D. (Eds). Handbook of climate change management: Research, leadership, transformation. Switzerland: Springer, pp. 1-18. https://doi. org/10.1007/978-3-030-22759-3_84-1

PGDS (PROVINCIAL GROWTH DEVELOPMENT STRATEGY). 2016. KwaZulu-Natal: Moving KZN towards achieving vision 2035. [Online]. Available at: <http://www.cesa.co.za/ sites/default/files/20161107_CESA\%20 Indaba_Implementation\%20SIPDM_ Rob\%20Kempen.pptx.pdf> [Accessed: 22 May 2020].

RAEMAEKERS, S. \& SOWMAN, M. 2015. Community-level socioecological vulnerability assessments in the Benguela Current Large Marine Ecosystem. Rome: FAO.

RSA (REPUBLIC OF SOUTH AFRICA). 1996. Constitution of the Republic of South Africa. [Online]. Available at: <https://www.gov.za/documents/ constitution-republic-south-africa-1996> [Accessed: 13 November 2020].

RSA (REPUBLIC OF SOUTH AFRICA). 1998. National Environmental Management Act, No. 107 of 1998. [Online]. Available at: <http://www. kruger2canyons.org/029\%20 -\%20NEMA.pdf> [Accessed: 13 November 2020].
RSA (REPUBLIC OF SOUTH AFRICA). 2015. Disaster Management Amended Act, No. 16 of 2015. [Online]. Available at: <https://www.gov.za/sites/default/ files/gcis_document/201512/39520ac t16of2015disastermanamendact.pdf> [Accessed: 13 November 2020].

RUGGIANO, N. \& PERRY, T.E. 2019.

Conducting secondary analysis of qualitative data: Should we, can we, and how? Qualitative Social Work, 18(1), pp. 81-97. https://doi. org/10.1177/1473325017700701

SALAMI, R.O., VON MEDING, J.K. \& GIGGINS, H. 2017. Vulnerability of human settlements to flood risk in the core area of Ibadan metropolis, Nigeria. Jàmbá: Journal of Disaster Risk Studies, 9(1), pp. 1-14. https://doi. org/10.4102/jamba.v9i1.371

SCHILLING, J., HERTIG, E., TRAMBLAY, Y. \& SCHEFFRAN, J. 2020. Climate change vulnerability, water resources and social implications in North Africa. Regional Environmental Change, 20(1), article number 15, pp. 1-12. https://doi.org/10.1007/ s10113-020-01597-7

SDF (UMKHANYAKUDE DISTRICT MUNICIPALITY SPATIAL DEVELOPMENT FRAMEWORK). 2019. [Online]. Available at: <http:// www.kzncogta.gov.za/wp-content/ uploads/2017/07/Umkhanyakude.zip> [Accessed: 22 May 2020].

SEGAL, N. \& CLOETE, B. 2012. Combating climate change: How might "green" growth facilitate or hinder SA's developmental objectives? Pretoria: DNA Economics.

SHAH, K.U., DULAL, H.B. \& AWOJOBI, M.T. 2020. Food security and livelihood vulnerability to climate change in Trinidad and Tobago. In: Connell, J. \& Lewitt, K. (Eds). Food security in small island states. Singapore: Springer, pp. 219-237. https://doi. org/10.1007/978-981-13-8256-7_12

SMIT, B. \& PILIFOSOVA, O. 2001. Adaptation to climate change in the context of sustainable development and equity. In: McCarthy, J.J., Canziani, O.F. \& Leary, N.A. (Eds). Climate change 2001: Impacts, adaptation and vulnerability, Chapter 18, pp. 879-906. 
UMKHANYAKUDE DISTRICT MUNICIPALITY CLIMATE CHANGE

VULNERABILITY ASSESSMENT AND

RESPONSE PLAN. 2019. Available

at: http://www.letsrespondtoolkit.

org/project-info/project-updates/ kzn-workshops/umkhanyakude-districtmunicipality-climate-change-reviewworkshop> [Accessed: 22 May 2020].

UN (UNITED NATIONS). 2016. Transforming our world: The 2030 Agenda for Sustainable Development. New York: United Nations. [Online]. Available at: <www. sustainabledevelopment.un.org> [Accessed: 15 June 2020].

UNICEF. 2011. Exploring the impact of climate change on children in South Africa. Pretoria: United Nations Children's Fund (UNICEF).

WIEDERKEHR, C., BECKMANN, M. \& HERMANS, K. 2018. Environmental change, adaptation strategies and the relevance of migration in subSaharan drylands. Environmental Research Letter, 13(11), article number 113003, pp. 1-18. https://doi. org/10.1088/1748-9326/aae6de

ZARAFSHANI, K., SHARAFI, L., AZADI, H. \& VAN PASSEL, S. 2016. Vulnerability assessment models to drought: Toward a conceptual framework. Sustainability, 8(6), article number 588, pp.1-21. doi:10.3390/ su8060588

ZIERVOGEL, G. \& ZERMOGLIO, F. 2009. Climate change scenarios and the development of adaptation strategies in Africa: Challenges and opportunities. Climate Research, 40(2-3), pp. 133-146. https://doi. org/10.3354/cr00804

ZIERVOGEL, G., NEW, M., ARCHER VAN GARDEREN, E., MIDGLEY, G.,

TAYLOR, A. \& HAMANN, R. et al. 2014. Climate change impacts and adaptation in South Africa. Wiley Interdisciplinary Reviews: Climate Change, 5(5), pp. 605-620. https://doi.org/10.1002/ wcc. 295 